\title{
The Role of Overconfident CEO to Dividend Policy in Industrial Enterprises*
}

\author{
Lam Xuan HOANG ${ }^{1}$, Duong Quy DANG ${ }^{2}$, Thuan Duc TRAN ${ }^{3}$ \\ Received: March 27, 2020 Revised: April 04, 2020 Accepted: June 07, 2020
}

\begin{abstract}
Researching the influence and role of CEO overconfidence to dividend policy is important for stock market investors. Therefore, this study was conducted to find out the relationship between CEO overconfidence and dividend policy in industrial enterprises in Vietnam. Data collected from 222 industry enterprises listed on the Vietnam Stock Exchange from 2012 to 2018. Data is collected on financial statements of listed companies. GLS model with panel data is used to analyze regression results. The results show that CEO overconfidence has dividend yield higher than CEO non-overconfidence. At the same time, the dividend payout ratio of enterprises has no difference between CEO overconfidence and CEO non-overconfidence. The results also showed that revenue growth has a positive impact on dividend yield in small enterprises, but negative impact on dividend payout in large enterprises. Research results by firm size have similar results with the general analysis for all enterprises. At the same time, the analysis of ownership type shows that CEO overconfidence has a positive impact on dividend yield of non-state enterprises without affecting other types of enterprises. From these results, the authors also made a number of recommendations to help investors choose businesses to invest in accordance with their strategies.
\end{abstract}

Keywords: CEO Overconfidence, Dividend Payout, Dividend Yield

JEL Classification Code: B26, C33, G40

\section{Introduction}

Dividend payment to shareholders is implemented by the Board of Directors to pay benefits to the shareholders who have contributed to the company (Masum, 2014). The dividends received are the investments of the shareholders in the company through the amount of shares held in the enterprises. Dividends paid are taken from the operating profits of the company, but the company does not always

${ }^{1}$ First Author. Huu Nghi University of Technology \& Management, Hanoi, Vietnam. Email: hoanglam@yahoo.com

${ }^{2}$ Corresponding Author. School of Business and Management, Vietnam National University, Vietnam [Postal Address: 144 Xuan Thuy Street, Cau Giay District, Hanoi, 100000, Vietnam] Email: duongdq@hsb.edu.vn

${ }^{3}$ Thuan Phat Import and Export Production Trading and Technical Services Company Limited, Ho Chi Minh, Vietnam. Email: tranthuaawila@gmail.com

(C) Copyright: The Author(s)

This is an Open Access article distributed under the terms of the Creative Commons Attribution Non-Commercial License (http://Creativecommons.org/licenses/by-nc/4.0/) which permits unrestricted noncommercial use, distribution, and reproduction in any medium, provided the original work is properly cited. pay dividends (Allen \& Saunders, 2002; Deshmukh et al., 2013; Masum, 2014). The dividend payment depends on the business strategies of the CEOs. For enterprises that want to attract long-term investment shareholders, they often restrict the dividend payment policy, and vice versa, in the short term, CEOs tend to pay more dividends. (Deshmukh et al., 2013; Nguyen, 2020).

According to previous studies, the change in dividend payment policy is greatly influenced by the CEO's overconfidence in enterprises. (Malmendier \& Tate, 2005; Nguyen, 2020). When the CEO is overconfident and expects that the future cash flow will be better (confident about business development in the coming years), they will tend to pay more dividends without caring much to risk (Wu \& Liu, 2011). However, there are also some CEOs who are confident and refrain from paying dividends due to the desire to invest in the long-term strategy (retained earnings continue to be reinvested for the future) (Ben-David et al., 2007; Deshmukh et al., 2013). At the same time, CEOs who are not overconfident tend to keep more profits in order to prevent risks in the coming years, and they tend to tighten the policy of paying dividends in the coming years (Ben-David et al., 2007). 
The industrialist is one of the industries that have contributed the most to Vietnam's economy in recent years. In 2019, the industry's contribution to the national GDP will reach $34.49 \%$ (GSO, 2019). The proportion of investment in the industry also accounts for the majority of Vietnam's stock market. With industry-specific characteristics, shareholders or investors often pay attention to the company's long-term development strategy. However, with the CEO's overconfidence, the policy of paying dividends in the industry may be different from the rest. In addition, in Vietnam, there have not been detailed studies to assess the impact of overconfident CEO on dividend policy of industrial enterprises. Therefore, this study will examine the role of the CEO who is overconfident in the dividend payment policy of industry enterprises listed on the Vietnam Stock Exchange from 2012 to 2018.

\section{Literature Review}

\subsection{Dividend Policy}

Dividend policy expressly decides between paying profits to shareholders and retaining profits for reinvestment. For dividend policy, the decision to distribute profits as dividends or retained profits for reinvestment does not alter the profit the company makes, but it affects the value of equity through impact on real incomes and current growth rates in the future (Deshmukh et al., 2013; Nguyen, 2020). The method of dividend policy on the enterprise can be based on Dividend yield and Dividend payout ratio.

The Dividend yield is the amount of money that companies extract from profits to pay to shareholders. People often calculate dividends on a stock. However, when comparing dividends between companies, pay attention to the dividend rate, this is a percentage between dividends and stock value. This indicator shows the percentage of dividend investors will receive compared to the amount payable to buy stocks. This index represents the percentage of profits extracted to pay to shareholders in the form of dividends. If this ratio is too large, the company will not reinvest profits appropriately (Bhattacharya, 1979; Deshmukh et al., 2013; Dong et al., 2005). A high dividend payout ratio often implies that the company's earnings are used largely to pay its shareholders and that the company is trying to attract investors to buy its stock.

The dividend payout ratio is the proportion of the total profits distributed in the form of dividends, the rest is called retained profit. The Dividend payment ratio is the amount of dividends paid to shareholders on the total net income of a company. The amount of money not earmarked to pay dividends to shareholders is held by the company for investment growth. The money held by the company is called retained earnings. Low-dividend payers, which are usually medium and small in size, have great potential for expansion; investors hope that after the time of good investment, this company will reinvest in revenue (Deshmukh et al., 2013; Masum, 2014). The expansion of projects has higher profitability and they benefit from the increase in stocks. In addition, the factor affecting the decision to pay low dividends is the tax on dividends. Therefore, to avoid taxes, these units instead pay dividends by buying treasury shares.

\subsection{CEO Overconfidence}

Overconfidence is a greater expectation of the future based on the decisions of the managers in the business, and they seem to ignore the risk factors that may be encountered. (Bharati et al., 2016). An excessively confident CEO often thinks that his ability is above average compared to other CEOs (Malmendier \& Tate, 2005; Wrońska-Bukalska, 2018). CEOs are overconfident when their behaviors are always performed at a higher level than their actual capacity, leading to decisions that can lead to personal mistakes, in turn leading to heavy losses for businesses. (Gervais et al., 2003). When the CEO's decisions are overconfident and bring good results, they consider this to be their ability and they become more confident with their decisions (Nguyen et al., 2020).

Overconfidence is measured by stock and option methods: Holder 67, Holder 150, Longholder and Net Buyer. The CEO holds options that exceed the reasonable thresholds to exercise the $67 \%$ or $150 \%$ option, which is the approach of the Holder 67 or Holder 150 metrics. The CEO by all means holds the option until the following maturity date - Five years or hold options that exceed reasonable benchmark thresholds. In order to build a measure of Net Buyer, Malmendier and Tate (2005) exploited the tendency of some CEOs to buy additional shares even though they sensed a high level of corporate risk. This study used the NetBuyer index to calculate and make judgments about overconfident and not-too-confident CEOs.

\section{Research Methods}

\subsection{Research Model and Hypotheses}

From the previous studies, the author's research model is presented as follows:

$$
\begin{aligned}
\text { DividendPolicy }_{i t}= & \alpha_{i}+\beta_{1} \text { Dividend Policy }_{i t-1}+\beta_{2} \\
& * \text { CEO Overconfidence } e_{i t}+\beta_{3} \\
& * \text { Control Variables } s_{i t}+\varepsilon_{i t}
\end{aligned}
$$

The research variables are detailed in Table 1. 
Table 1: Definition of variables

\begin{tabular}{|c|c|c|}
\hline Variables & Symbol & Definition \\
\hline \multirow[t]{2}{*}{$\begin{array}{l}\text { Dependent } \\
\text { variable: } \\
\text { Dividend Policy }\end{array}$} & DYield & Dividend Yield \\
\hline & DPayout & Dividend Payout \\
\hline \multicolumn{3}{|l|}{$\begin{array}{l}\text { Independent } \\
\text { variables: }\end{array}$} \\
\hline $\begin{array}{l}\text { Over } \\
\text { Confidence }\end{array}$ & OV & $\begin{aligned} & =1 \text { if OverConfidence } \\
= & 0 \text { if no OverConfidence }\end{aligned}$ \\
\hline \multicolumn{3}{|l|}{$\begin{array}{l}\text { Control } \\
\text { variables }\end{array}$} \\
\hline Firm size & SIZE & Ln (total assets) \\
\hline $\begin{array}{l}\text { Revenure } \\
\text { Growth }\end{array}$ & GROWTH & $\begin{array}{c}\left(\text { Total sales }_{t}-\text { total } \text { sales }_{t-1}\right) / \\
\text { total sales } \\
\text { t-1 }\end{array}$ \\
\hline Age of firm & AGE & Number of activities \\
\hline
\end{tabular}

The dependent variable in the model is measured through two indicators, Dividend Yield and Dividend Payout. Also, the independent variable is Overconfidence - Dummy variable $(\mathrm{OV})$ if the $\mathrm{CEO}$ is overconfident then $\mathrm{OV}=1$ and $\mathrm{OV}=0$ if the CEO is not overconfident. Besides, the study also conducted using control variables such as: Firm size, Revenue growth; number of years listed

CEO Overconfidence: The CEO's overconfidence shows in his decisions within the company. The CEOs who are overconfident tend to pay more dividends in the short term as the CEO thinks that decisions will produce profits in the next few years. Therefore, the CEO does not like to care about the risk that leads to reduced retention and increased dividend payments for the business. In this study, the specific data is seven years, so the authors only care about the impact in the short term. Therefore, the research hypothesis is given as follows:

H1: CEO Overconfidence has a positive impact on Dividend Policy

Firm size: the size of the enterprises represents the total assets of the business. With businesses increasing in size to serve production and business activities, it will cost more capital to invest. Therefore, the business may use more profits to reinvest instead of paying more dividends. Therefore, the research hypothesis is given:

H2: Size has a negative impact on Dividend Policy

GROWTH: represents the revenue growth factor in businesses. Creating more revenue will be a signal that firm performance is on the rise. This will help the cash flow in the business to maintain better leading to the CEO will tend to pay more dividends. The research hypothesis is stated as follows:

\section{H3: Growth has a positive impact on Dividend Policy}

Age: The number of years the firm is listed on the stock market indicates its experience on the stock exchange in attracting investors. The longer listed companies will have more strategies in signaling to investors to attract capital as well as increase the value of businesses. One of the affected policies is Dividend Policy. To attract investors, CEOs tend to increase dividend payments to benefit investors holding shares. Therefore, the next research hypothesis is as follows:

H4: The number of years the firm's listing has a positive impact on Dividend Policy

\subsection{Data and Research Method}

The research data is used based on the report of industry enterprises listed on Vietnam's stock market from 2012 to 2018. The data, after being collected in the financial statements of enterprises, will be included in the STATA software for analysis. With research data from 2012 to 2018 for industrial enterprises, panel data is considered suitable for analysis. For the panel data model, the analysis models are fixed effect model (FEM), random effect model (REM). A Hausman test will be performed to find an appropriate model between FEM and REM. Next, tests of autocorrelation and heteroskedasticity will be performed to assess the reliability of the model (Nguyen, 2020; Nguyen, 2020b). In case the selected model satisfies the tests, it will be included in the final results analysis. Conversely, when the model has autocorrelation or heteroskedasticity, it will be corrected through GLS models.

In addition, the study also conducted an analysis of the influence of CEO's overconfidence on dividend policy in enterprises of different size and different types of ownership. The division of enterprises types will be based on the stateforeign ownership ratio and other ownership, the median value of the variables in total assets,

\section{Results}

\subsection{Descriptive Statistics}

Quantitative variables in the research model are included in the descriptive statistical analysis. The descriptive analysis results show that the mean of Dividend Yield is 0.062 in which the largest is 0.233 and the smallest is 0 . For the mean of Dividend Payout is 0.427 in which the largest is 1.093 and the smallest is 0 . The mean of total assets VND1.32 trillion, the largest is VND 28.4 trillion and the smallest 
is VND15.7 billion. The mean of revenue growth reached 0.088 , equivalent to $8.8 \%$ / year, of which the largest revenue growth was $102 \%$ / year and the smallest was $-45 \%$ / year. For the number of years listed, the mean of number of years listed up to 2018 is six years and a maximum of 12 listings on the stock exchange. Detailed indicators in Table 2.

For qualitative variables are given and the frequency is described. The descriptive results show that research data as of 2018 has 192 CEOs Overconfidence (86.49\%) and 30 nonOverconfidence CEOs (13.51\%). In addition, the enterprises that collect the analysis are mainly non-state enterprises (169 non-state enterprises accounted for $76.13 \%$ ), the number of state enterprises accounted for $23.87 \%$ (53 state enterprises). Details are in Table 3.

\subsection{Regression Analysis}

With both FEM and REM models, both the model defects in autocorrelation and the heteroskedasticity, so the model will be corrected through GLS for analyzing model results. The analysis results for all of the enterprises are shown in Table 4. The analysis results with two dependent variables: Dividend Yield and Dividend Payout show that CEO Overconfidence has the same directional influence on Dividend Policy (positive and positive beta coefficients). Statistically significant at 5\%), but does not affect Dividend Payout at the 5\% significance level. This result indicates that CEO Overconfidence tends to pay Dividend Yield more than CEO non-Overconfidence. For industry, overconfident CEOs tend to pay more dividends when expecting better business results in the coming years. This may be a signal of businesses wanting to make investors more interested in their shares when it is clear that Dividend Yield is very good for shareholders. As a result, investors can invest in industrial companies with CEOs who are overconfident in order to gain benefits in the short term. The fact that CEO
Overconfidence does not affect Dividend Payout shows that there is no difference in the rate of dividend payment in the business with the CEO being overconfident and the CEO not overconfident. It can be seen that enterprises do not have a strategy for Dividend Payout rate but only focus on Dividend Yield to attract shareholders holding more shares.

The analysis of firm size also shows that the impact of overconfident CEOs of small and large enterprises is the same on Dividend Yield (Overconfident CEOs have a higher level of Dividend Yield than CEOs non-Overconfident at both small and large scales). Besides, an overconfident CEO has not impact on Dividend Payout in all types of firm sizes. Research results by firm size have similar results with the general analysis for all enterprises (see Table 4, 5, and 6).

Regarding the results of the classification by ownership type, CEO Overconfidence only affects the same direction on Dividend Yield of non-state enterprises without affecting other types of enterprises. This result indicates that nonstate enterprises tend to operate as well as Dividend Policy similar to the whole industry. State-owned enterprises with operational characteristics leading to CEO's decisions are also different from non-state enterprises regarding Dividend Yield. For the control variables, the analysis also shows that Growth has a positive impact on Dividend Yield in small enterprises, but the negative effect on Dividend Payout in large enterprises. At the same time, Growth is also on the same path as Dividend Yield in both types of state-owned and non-state enterprises. The Age variable only negatively affects Dividend Payout in large enterprises, showing that the larger the number of years of listing, the lower the dividend payment rate. It can be seen that long-time listed companies focus more on the long-term so the retained profit rate tends to increase to invest in the future more. The remaining control variables do not affect the Dividend Policy of industrial enterprises (see Table 4, 5, and 6).

Table 2: Summary Statistics

\begin{tabular}{|l|c|c|c|c|}
\hline \multicolumn{1}{|c|}{ VarName } & Mean & SD & Min & Max \\
\hline div_yield & 0.062 & 0.067 & 0 & 0.233 \\
\hline div_payout & 0.427 & 0.389 & $1.57 \mathrm{e}+10$ & 2.093 \\
\hline asset & $1.32 \mathrm{e}+12$ & $2.76 \mathrm{e}+12$ & -0.450 & 1.020 \\
\hline growth & 0.088 & 0.328 & 7 & 12 \\
\hline age & 6.509 & 3.062 & & 12 \\
\hline
\end{tabular}

Table 3: Information of enterprises

\begin{tabular}{|c|c|c|c|}
\hline & & Freq. & Percent \\
\hline OV & Non-Overconfidence & 192 & 86.49 \\
\hline State & Overconfidence & 30 & 13.51 \\
\hline & Others & 169 & 76.13 \\
\hline
\end{tabular}


Table 4: Regression analysis results for all companies

\begin{tabular}{|c|c|c|c|c|c|c|}
\hline \multirow[b]{2}{*}{ VARIABLES } & \multicolumn{3}{|c|}{ Dependent variable: Dividend Yield } & \multicolumn{3}{|c|}{ Dependent variable: Dividend Payout } \\
\hline & FEM & REM & GLS & FEM & REM & GLS \\
\hline \multirow[t]{2}{*}{ div_yield $_{t-1}$} & $0.216^{* * *}$ & $0.590^{* * *}$ & $0.590^{* * *}$ & & & \\
\hline & $(0.0299)$ & $(0.0211)$ & $(0.0210)$ & & & \\
\hline \multirow[t]{2}{*}{ div_payout ${ }_{t-1}$} & & & & $0.147^{* * *}$ & $0.609^{* * *}$ & $0.609^{* * *}$ \\
\hline & & & & $(0.0309)$ & $(0.0229)$ & $(0.0229)$ \\
\hline \multirow[t]{2}{*}{ OV } & 0.00658 & $0.00973^{* * *}$ & $0.00973^{* * *}$ & -0.00831 & $0.0394^{*}$ & $0.0394^{*}$ \\
\hline & $(0.00425)$ & $(0.00376)$ & $(0.00375)$ & $(0.0249)$ & $(0.0229)$ & $(0.0229)$ \\
\hline \multirow[t]{2}{*}{ SIZE } & 0.00201 & -0.000262 & -0.000262 & -0.0213 & -0.00586 & -0.00586 \\
\hline & $(0.00472)$ & $(0.00110)$ & $(0.00110)$ & $(0.0277)$ & $(0.00673)$ & $(0.00672)$ \\
\hline \multirow[t]{2}{*}{ GROWTH } & $0.0173^{* * *}$ & $0.0139^{* \star *}$ & $0.0139^{* * *}$ & 0.00463 & -0.0222 & -0.0222 \\
\hline & $(0.00473)$ & $(0.00453)$ & $(0.00452)$ & $(0.0277)$ & $(0.0276)$ & $(0.0276)$ \\
\hline \multirow[t]{2}{*}{ AGE } & $-0.00252^{* * *}$ & -0.000489 & -0.000489 & -0.00406 & -0.00328 & -0.00328 \\
\hline & $(0.000921)$ & $(0.000510)$ & $(0.000509)$ & $(0.00545)$ & $(0.00313)$ & $(0.00312)$ \\
\hline \multirow[t]{2}{*}{ Constant } & 0.00822 & 0.0309 & 0.0309 & 0.975 & $0.348^{*}$ & $0.348^{*}$ \\
\hline & $(0.124)$ & $(0.0292)$ & $(0.0292)$ & $(0.731)$ & $(0.179)$ & $(0.179)$ \\
\hline Observations & 1,330 & 1,330 & 1,330 & 1,330 & 1,330 & 1,330 \\
\hline Number of $\mathrm{i}$ & 222 & 222 & 222 & 222 & 222 & 222 \\
\hline
\end{tabular}

Standard errors in parentheses

${ }^{* * *} p<0.01,{ }^{* *} p<0.05,{ }^{*} p<0.1$

Results of Hausman analysis and testing to find a model that is suitable for the research data show that FEM model is more suitable than the REM model. However, on the FEM model, both autocorrelation and variance of variance exist ( $p$-value of autocorrelation test and variance of variation are less than 0.05 )

Table 5: Analysis results for enterprises by firm size

\begin{tabular}{|l|c|c|c|c|}
\hline \multirow{2}{*}{ VARIABLES } & \multicolumn{2}{|c|}{ Dependent variable: Dividend Yield } & \multicolumn{2}{c|}{ Dependent variable: Dividend Payout } \\
\cline { 2 - 5 } & Small & Lagre & Small & Lagre \\
\hline div_yield t-1 $^{*}$ & GLS & GLS & GLS \\
\hline & $0.589^{* * *}$ & $0.589^{* * *}$ & & \\
\hline div_payout $_{\mathrm{t}-1}$ & -0.0301 & -0.0293 & $0.614^{* * *}$ & $0.604^{* * *}$ \\
\hline & & & -0.0326 & -0.0319 \\
\hline OV & & & 0.0467 & 0.027 \\
\hline \multirow{2}{*}{} & $0.00990^{*}$ & $0.0091^{*}$ & -0.0316 & -0.0329 \\
\hline SIZE & -0.0052 & -0.0054 & -0.0037 & -0.0037 \\
\hline & 0.00046 & -0.0008 & -0.0186 & -0.0141 \\
\hline GROWTH & -0.0031 & -0.0023 & 0.0659 & $-0.091^{* *}$ \\
\hline & $0.0296^{* *}$ & 0.00057 & -0.0402 & -0.0378 \\
\hline
\end{tabular}




\begin{tabular}{|l|c|c|c|c|}
\hline AGE & -0.0002 & -0.0005 & 0.0031 & $-0.009^{*}$ \\
\hline & -0.0007 & -0.0007 & -0.0043 & -0.0046 \\
\hline Constant & 0.00952 & 0.0475 & 0.241 & 0.346 \\
\hline & -0.0791 & -0.0638 & -0.48 & -0.391 \\
\hline obs & 649 & 681 & 649 & 681 \\
\hline Number of $\mathrm{i}$ & 130 & 135 & 130 & 135 \\
\hline
\end{tabular}

Standard errors in parentheses

${ }^{* * *} p<0.01,{ }^{* *} p<0.05,{ }^{*} p<0.1$

Results of Hausman analysis and testing to find a model that is suitable for the research data show that FEM model is more suitable than the REM model. However, on the FEM model, both autocorrelation and variance of variance exist ( $p$-value of autocorrelation test and variance of variation are less than 0.05 )

Table 6: Analysis results for enterprises classified by ownership type

\begin{tabular}{|l|c|c|c|c|}
\hline & \multicolumn{2}{|c|}{ Dependent variable: Dividend Yield } & \multicolumn{2}{c|}{ Dependent variable: Dividend Payout } \\
\hline & State Ownership & Others & StateOwnership & Others \\
\hline \multicolumn{1}{|c|}{ VARIABLES } & GLS & GLS & GLS & GLS \\
\hline div_yield $t-1$ & $0.677^{* *}$ & $0.531^{* *}$ & & \\
\hline & -0.0387 & -0.0253 & & $0.580^{* * *}$ \\
\hline div_payout ${ }_{\mathrm{t}-1}$ & & & $-652^{* *}$ & -0.0266 \\
\hline & & & -0.0468 & 0.038 \\
\hline OV & -0.0016 & $0.0134^{*}$ & 0.0522 & -0.0261 \\
\hline & -0.0080 & -0.0041 & -0.0462 & -0.00264 \\
\hline SIZE & -0.0012 & $-8.6 \mathrm{E}-5$ & -0.0185 & -0.00807 \\
\hline & -0.0020 & -0.0012 & -0.0122 & -0.0213 \\
\hline GROWTH & $0.0278^{*}$ & $0.0118^{*}$ & -0.0022 & -0.03 \\
\hline & -0.0126 & -0.0048 & -0.0729 & -0.00316 \\
\hline AGE & -0.0006 & -0.0004 & -0.0041 & -0.00349 \\
\hline & -0.0011 & -0.0005 & -0.0069 & 0.256 \\
\hline Constant & 0.0624 & 0.0263 & $0.721^{* *}$ & -0.214 \\
\hline & -0.0559 & -0.0341 & -0.327 & 1,012 \\
\hline obs & 318 & 1,012 & 318 & 169 \\
\hline Number of i & 53 & 169 & 53 & \\
\hline
\end{tabular}

Standard errors in parentheses

${ }^{* * *} p<0.01,{ }^{* *} p<0.05,{ }^{*} p<0.1$

Results of Hausman analysis and testing to find a model that is suitable for the research data show that FEM model is more suitable than the REM model. However, on the FEM model, both autocorrelation and variance of variance exist ( $p$-value of autocorrelation test and variance of variation are less than 0.05

\section{Conclusion}

A study to assess the impact of overconfident CEO on dividend policy in industrial enterprises has shown that there is a difference in dividend policy of overconfident and non-overconfident CEOs. The analysis results show that
Dividend Yield's CEOs are more confident than those whose CEOs are not overconfident. The results also show that the CEO is overconfident to affect Dividend Payout. The results of this research will help investors interested in Dividend Yield to focus on businesses with overconfident CEOs and non-state enterprises. 


\section{References}

Allen, L., \& Saunders, A. (2002). A Survey of Cyclical Effects in Credit Risk Measurement Models (SSRN Scholarly Paper ID 1295817). Social Science Research Network. https://papers. ssrn.com/abstract $=1295817$

Ben-David, I., Graham, J. R., \& Harvey, C. R. (2007). Managerial Overconfidence and Corporate Policies (Working Paper No. 13711). National Bureau of Economic Research. https://doi. org/10.3386/w13711

Bharati, R., Doellman, T., \& Fu, X. (2016). CEO confidence and stock returns. Journal of Contemporary Accounting \& Economics, 12(1), 89-110. https://doi.org/10.1016/j. jcae.2016.02.006

Bhattacharya, S. (1979). Imperfect Information, Dividend Policy, and "The Bird in the Hand" Fallacy. The Bell Journal of Economics, 10(1), 259-270. https://doi.org/10.2307/3003330

Deshmukh, S., Goel, A. M., \& Howe, K. M. (2013). CEO overconfidence and dividend policy. Journal of Financial Intermediation, 22(3), 440-463. https://doi.org/10.1016/j. jfi.2013.02.003

Dong, M., Robinson, C., \& Veld, C. (2005). Why individual investors want dividends. Journal of Corporate Finance, 12(1), 121-158. https://doi.org/10.1016/j.jcorpfin.2004.04.006

Gervais, S., Heaton, J. B., \& Odean, T. (2003). Overconfidence, Investment Policy, and Executive Stock Options. SSRN Electronic Journal. https://doi.org/10.2139/ssrn.361200
Malmendier, U., \& Tate, G. (2005). Does Overconfidence Affect Corporate Investment? CEO Overconfidence Measures Revisited. European Financial Management, 11(5), 649-659. https://doi.org/10.1111/j.1354-7798.2005.00302.x

Masum, A. (2014). Dividend Policy and Its Impact on Stock PriceA Study on Commercial Banks Listed in Dhaka Stock Exchange (SSRN Scholarly Paper ID 2724964). Social Science Research Network. https://papers.ssrn.com/abstract=2724964

Nguyen, T. O. (2020). Factors Affecting the Intention to Use Digital Banking in Vietnam. Journal of Asian Finance, Economics and Business, 7(3), 303-310. https://doi.org/10.13106/jafeb.2020. vol7.no3.303

Nguyen, T. V. (2020b). The Role of Foreign Direct Investment and Trade on Environmental Quality in Vietnam. Journal of Asian Finance, Economics and Business, 7(3), 289-294. https://doi. org/10.13106/jafeb.2020.vol7.no3.289

Nguyen, V. D., Dang, Q. D., Pham, H. G., \& Do, K. D. (2020). Influence of Overconfidence and Cash Flow on Investment in Vietnam. Journal of Asian Finance, Economics and Business, 7(2), 99-106. https://doi.org/10.13106/jafeb.2020.vol7.no2.99

Wrońska-Bukalska, E. (2018). Power of an overconfident CEO and dividend payment. Journal of Management and Financial Sciences, 35, 61-80.

Wu, C.-H., \& Liu, V. W. (2011). Payout Policy and CEO Overconfidence. Working Paper. 